\title{
Seven Times Weekly
}

National Cancer Institute

\section{Source}

National Cancer Institute. Seven Times Weekly. NCI Thesaurus. Code C98854.

Seven times per week. 